\title{
Double-Filtration Plasmapheresis plus IFN for HCV-1b Patients with Non-Sustained Virological Response to Previous Combination Therapy: Early Viral Dynamics
}

\author{
Soo Ryang Kim ${ }^{a}$ Susumu Imoto ${ }^{a}$ Masatoshi Kudo ${ }^{d}$ Keiji Mita ${ }^{a}$ \\ Miyuki Taniguchi $^{\mathrm{a}} \mathrm{Ke} \mathrm{Ih} \mathrm{Kim}^{\mathrm{a}}$ Noriko Sasase $^{\mathrm{a}}$ Ikuo Shoji $^{\mathrm{b}}$ \\ Motoko Nagano-Fujii ${ }^{b}$ Ahmed El-Shamy ${ }^{b}$ Hak Hotta $^{b}$ Tomoyuki Nagai ${ }^{d}$

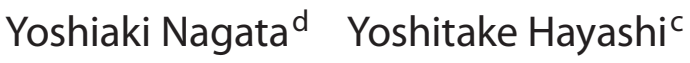 \\ a Department of Gastroenterology, Kobe Asahi Hospital, b Department of Microbiology, and \\ 'Center for Infectious Diseases, Kobe University Graduate School of Medicine, Kobe, and \\ ${ }^{\mathrm{d}}$ Department of Gastroenterology and Hepatology, Kinki University School of Medicine, Osaka-Sayama, Japan
}

\section{Key Words}

Chronic hepatitis C - Double-filtration plasmapheresis •

Early viral dynamics $\cdot$ Genotype $1 \mathrm{~b} \cdot$ High viral load .

Interferon $\beta \cdot$ Non-sustained virological responder •

Peginterferon plus ribavirin combination therapy

\begin{abstract}
Double-filtration plasmapheresis (DFPP) was approved in Japan in April 2008 for the retreatment of chronic hepatitis C patients with genotype $1 \mathrm{~b}$ and high viral loads, whose hepatitis $C$ virus was not eradicated by earlier IFN therapy or by pegylated IFN plus ribavirin (PEG-IFN/RBV) combination therapy. In this study, we assessed the early viral dynamics of 9 patients with non-sustained virological response to the combination therapy. The overall viral dynamics of DFPP plus IFN treatment with or without RBV for 4 weeks showed a reduction of $\geq 1$ log in the viral load in $22 \%$ ( 2 of 9 patients), $55.6 \%$ (5/9), 77.8\% (7/9) and 77.8\% (7/9) at 24 h, 1, 2 and 4 weeks after the start of treatment. By contrast, DFPP plus
\end{abstract}

consecutive intravenous IFN- $\beta$ for 4 weeks reduced the viral load by $\geq 1 \log$ in $33 \%(2 / 6), 50 \%(3 / 6), 83.3 \%(5 / 6)$ and $83.3 \%$ $(5 / 6)$ at 24 h, 1, 2 and 4 weeks. The viral load declined by $\geq 2$ log in 50\% (3/6) at 4 weeks after the start of treatment. DFPP plus consecutive intravenous IFN- $\beta$ for 4 weeks is a promising treatment for non-sustained virolgical response patients.

Copyright $\odot 2010$ S. Karger AG, Basel

\section{Introduction}

Hepatitis $\mathrm{C}$ virus (HCV) infection is the major cause of chronic hepatitis, liver cirrhosis, and hepatocellular carcinoma (HCC) in industrialized countries. HCV infection is manageable, however, and its complications can be prevented by antiviral therapy $[1,2]$. Currently, the most effective treatment for chronic $\mathrm{HCV}$ infection is based on pegylated interferon plus ribavirin (PEG-IFN/ RBV) combination therapy [3]. Nonetheless, sustained

\section{KARGER}

Fax +41613061234 E-Mail karger@karger.ch www.karger.com
(C) 2010 S. Karger AG, Basel

$0300-5526 / 10 / 0531-0044 \$ 26.00 / 0$

Accessible online at:

www.karger.com/int
Soo Ryang Kim, MD

Department of Gastroenterology

Kobe Asahi Hospital

3-5-25 Bououji-cho, Nagata-ku, Kobe 653-0801 (Japan)

Tel. +81 78612 5151, Fax +81 78612 5152, E-Mail asahi-hp@arion.ocn.ne.jp 
virological response (SVR) rates for those infected with the most resistant genotypes (HCV-1a and HCV-1b) still hover around $50 \%[3,4]$.

To surmount this SVR rate with combination therapy, several trials have been undertaken, two of which are: (1) retreatment with combination therapy and (2) doublefiltration plasmapheresis (DFPP). By the protocol-defined primary analysis of the former, the SVR rate has been $16 \%$ at most, even for a 72 -week induction group [5].

The use of DFPP [approved in Japan in April 2008 for the retreatment of chronic hepatitis $\mathrm{C}(\mathrm{CHC})$ patients with genotype $1 \mathrm{~b}$ and high viral loads] together with IFN administration has produced a substantial reduction in the viral load during the early stages of treatment and has effected a high SVR [6], suggesting that this treatment is a new modality for CHC patients in difficult-to-treat states. In this study, we used DFPP plus IFN to enhance the efficacy of the treatment of CHC patients whose $\mathrm{HCV}$ was not eradicated by earlier PEG-IFN/RBV combination therapy, and we assessed early viral dynamics associated with SVR.

\section{Patients and Methods}

\section{Patients}

Nine patients (aged 43-66 years) whose HCV had not been eradicated by earlier PEG-IFN $\alpha$-2b plus RBV combination therapy carried out between 2008 and 2009 were enrolled in this study. The patients were divided into 2 groups: partial responders (PR; relapse after the end of therapy) and non-responders (NR; no disappearance of HCV RNA during therapy). All the patients were confirmed to be HCV RNA positive with high transaminase levels persisting for 6 months or longer, and with HCV RNA genotype $1 \mathrm{~b}$ at levels exceeding $10^{5} \mathrm{log} \mathrm{IU} / \mathrm{ml}$ in blood (as determined before the start of therapy by real-time PCR). Also, the patients were negative for hepatitis B surface antigen. Patients with platelet counts of $\leq 10 \times 10^{4} / \mu$ l, leukocyte counts of $\leq 3,000 / \mu \mathrm{l}$, or hemoglobin levels of $\leq 12 \mathrm{~g} / \mathrm{dl}$ were excluded from the study.

Each patient gave written informed consent and agreed to receive concomitant DFPP, and the study was approved by the review board of the Kobe Asahi Hospital.

\section{DFPP and Blood Collection}

Blood collected from the peripheral vein for DFPP by a Plasmaflo ${ }^{\mathrm{TM}}$ OP-18W filter (Asahi Kasei Medical, Tokyo, Japan) was separated into plasma and cell components. The virus was then removed from the plasma by a second filter (Cascadeflo ${ }^{\mathrm{TM}}$ EC50W; Asahi Kasei Medical) of an average pore size of $30 \mathrm{~nm}$. For each session, the final volume of treated plasma was $50 \mathrm{ml} / \mathrm{kg}$; the number of sessions was 5 over 2 weeks, and the time of DFPP, based on the reduced plasma fibrinogen levels during DFPP, was decided by the physicians and as required by the patients.
Types of IFN for 4 Weeks with DFPP

During DFPP, the patients were treated with different kinds of IFN: patient 1 with PEG-IFN $\alpha$-2b plus RBV for 4 weeks; patients 2 and 3 with IFN- $\beta 3$ MU twice daily for 2 weeks and PEG-IFN $\alpha$ 2 a plus RBV for 2 weeks; patients 4 and 9 with IFN- $\beta 3$ MU twice daily for 2 weeks and IFN- $\beta 6$ MU daily for 2 weeks; patient 5 with IFN- $\beta 3$ MU twice daily for 10 days and IFN- $\beta 6$ MU daily for 18 days, and patients 6,7 and 8 with IFN- $\beta 3$ MU twice daily for 4 weeks. The dose of PEG-IFN $\alpha-2 b$ was $1.5 \mu \mathrm{g} / \mathrm{kg}$ and $180 \mu \mathrm{g}$ of $\alpha$ 2a per week. The RBV dose was $800 \mathrm{mg} /$ day with $\alpha-2 \mathrm{~b}$ and $600-$ $800 \mathrm{mg} /$ day with $\alpha-2 \mathrm{a}$. After DFPP plus IFN treatment for 4 weeks, all patients were scheduled to receive PEG-IFN/RBV combination therapy (patient 1: PEG-IFN $\alpha-2 b 1.5 \mu \mathrm{g} / \mathrm{kg}$ per week plus RBV $800 \mathrm{mg} /$ day; patients 2-9: PEG-IFN $\alpha$-2a $180 \mu \mathrm{g}$ per week plus RBV 600-800 mg/day).

Amino Acid Substitutions in the Core Region (aa 30 and a a 91) and Number of IFN Sensitivity-Determining Region Mutations

We measured pre-treatment factors such as prediction of clinical outcome of therapy, amino acid sequence variation in the NS5A region (referred to as IFN sensitivity-determining regions) and in the core protein regions (aa 70 and aa 91) of HCV with a given genotype, and the viral load.

\section{HCV RNA Measurement}

The quantity of HCV RNA was measured by real-time PCR (detection limit $1.2 \log \mathrm{IU} / \mathrm{ml}$ ), by HCV core antigen (detection limit $20 \mathrm{fmol} / \mathrm{l}$ ), and by RT-PCR (Amplicor HCV monitor v 2.0; Roche; detection limit $50 \mathrm{IU} / \mathrm{ml}$ ).

\section{Virus Removal at Second Filter Inlet and Outlet}

Plasma was collected twice from the inlet and outlet of the second filter during 1 session of DFPP: once when the treated plasma volume reached half of the target quantity, and once when DFPP was completed. The change in the quantity of HCV RNA was evaluated through the plasma samples collected.

Viral Reduction and Viral Response Rate

The quantity of HCV RNA was converted to a log value at the beginning of the treatment $(\mathrm{A})$ and at each of the virus measurement points (B). $\Delta \log$ was then calculated: $\Delta \log =\log \mathrm{A}-\log \mathrm{B}=$ $\log (\mathrm{A} / \mathrm{B})$.

\section{Evaluation of DFPP Safety}

The subjective and objective adverse events of DFPP were observed, and five clinical factors were measured (platelet and lymphocyte counts, and hemoglobin, albumin and fibrinogen levels) before the first session of DFPP, before successive sessions on the second, third, fourth, fifth and sixth days, and 2 weeks after the last session.

\section{Statistical Analysis}

Statistical analysis consisted of analysis of variance for patient background factors, and the paired t test for quantities of $\mathrm{HCV}$ RNA at the second filter inlet during DFPP. The t test was used for viral load reductions and Fisher's exact test for viral response rates among the groups. The t test was 2 -tailed, and differences of $\mathrm{p}<0.05$ were considered significant. 


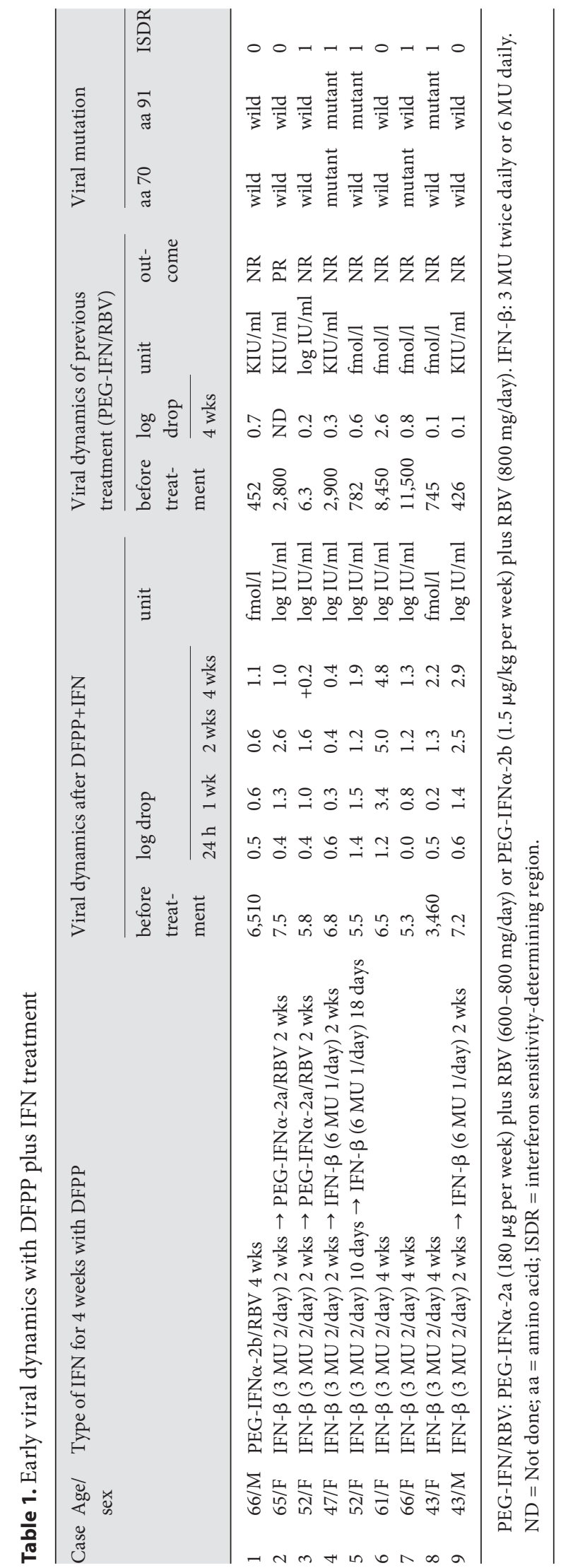

\section{Results}

Of the 9 patients, 1 was PR and 8 were NR. Virus mutation in the core region was as follows: wild type (7 patients) and mutant type (2 patients) at aa 70 ; wild type (6 patients) and mutant type ( 3 patients) at aa 91. IFN sensitivity-determining regions demonstrated mutation 1 (5 patients) and mutation 0 (4 patients), while mutation 2 was not seen in any patient. The overall viral dynamics of DFPP plus IFN treatment with or without RBV for 4 weeks showed a reduction in the viral load of $\geq 1 \log$ in $22 \%$ ( 2 of 9 patients), 55.6\% (5/9), $77.8 \%$ (7/9) and 77.8\% (7/9) at $24 \mathrm{~h}, 1,2$ and 4 weeks after the start of treatment, respectively. The early viral dynamics after DFPP plus consecutive intravenous IFN- $\beta$ treatment for 4 weeks showed a reduction in the viral load of $\geq 1 \log$ in $33 \%$ ( 2 of 6 patients), $50 \%(3 / 6), 83.3 \%(5 / 6)$ and $83.3 \%(5 / 6)$ at $24 \mathrm{~h}, 1,2$ and 4 weeks after the start of treatment, respectively. The reduction of the viral load by $\geq 2 \log$ was observed in $50 \%$ ( 3 of 6 patients) at 4 weeks after the start of treatment (table 1).

\section{Discussion}

New drugs to replace IFN as well as drugs that can be used in combination with IFN are being actively developed. Also, attempts are being made to find ways to physically remove HCV particles from the blood. Granulocyte apheresis, plasma exchange and hemofiltration have been applied to HCV-infected patients for the treatment of cryoglobulinemia and vasculitis, modalities which have been shown to reduce HCV RNA in the blood during treatment [6-11]. The mechanisms of the clinical results of plasmapheresis have been described, whereby $\mathrm{HCV}$ in the blood is related to the effects of IFN therapy that could be enhanced by removing the virus from blood [12-14]. Low-density lipoprotein-cholesterol apheresis and plasma exchange in hypercholesteremic patients with HCV infection reduces the quantity of HCV RNA in the blood of some patients [15]. Hemodialysis, hemofiltration and peritoneal dialysis in chronic dialysis patients infected with HCV significantly lower HCV RNA levels in the blood [16]. Combined granulocyte apheresis with IFN therapy for CHC [17-19] and the prerequisite for early reduction of the virus in the treatment of $\mathrm{CHC}$ $[20,21]$ are essential. Thus, the potential effectiveness of IFN therapy combined with early physical removal of the virus is of particular interest. 
Asahina et al. [22] studied HCV dynamics in both serum and peripheral blood mononuclear cells in $44 \mathrm{pa}-$ tients, with HCV genotype $1 \mathrm{~b}$ and high viral loads, randomly assigned to 4 treatment groups: (1) combination therapy with $6 \mathrm{MU}$ daily of IFN $\alpha-2 \mathrm{~b}$ plus $800 \mathrm{mg}$ of RBV; (2) monotherapy with $6 \mathrm{MU}$ daily of IFN $\alpha-2 b$; (3) monotherapy with twice-daily intravenous administration of 3 MU of IFN- $\beta$, and (4) monotherapy with daily intravenous administration of $6 \mathrm{MU}$ of IFN- $\beta$. HCV RNA levels measured serially by highly sensitive real-time PCR and $\mathrm{HCV}$ dynamics in both serum and peripheral blood mononuclear cells have demonstrated a 'biphasic' pattern. The exponential decay slopes of the second phase have been significantly higher in the combination or the twice-daily dose regimen groups than in group 2 or 4 $(0.10 \pm 0.08$ vs. $0.02 \pm 0.09$ or $0.16 \pm 0.09$ vs. $0.02 \pm$ $0.04 \mathrm{day}^{-1} ; \mathrm{p}<0.05$ and $\mathrm{p}<0.0005$, respectively) [22]. Kim et al. [23] observed that a daily dose of IFN- $\beta 6$ MU for 4 weeks effects a 2 log decrease in the HCV RNA load in 7 patients with genotype $1 \mathrm{~b}$ and high viral loads.

In this study, early viral dynamics were assessed in the 9 patients non-SVR to the combination therapy. The overall viral dynamics of DFPP plus IFN treatment with or without RBV for 4 weeks reduced the viral load by $\geq 1$ $\log$ in $22 \%$ ( 2 of 9 patients), $55.6 \%$ (5/9), $77.8 \%$ (7/9), and $77.8 \%(7 / 9)$ at $24 \mathrm{~h}, 1,2$ and 4 weeks after the start of treatment, respectively. DFPP plus consecutive intravenous IFN- $\beta$ treatment for 4 weeks reduced the viral load by $\geq 1$ $\log$ in $33 \%(2 / 6), 50 \%(3 / 6), 83.3 \%(5 / 6)$ and $83.3 \%(5 / 6)$ at $24 \mathrm{~h}, 1,2$ and 4 weeks after the start of treatment, respectively.

The prerequisite for early virological response (EVR; indicating negative HCV RNA at 12 weeks) has been em- phasized in predicting SVR and non-SVR in CHC patients undergoing IFN treatment; those who do not reach EVR fail to respond to further therapy. Treatment discontinued in patients not reaching EVR would reduce drug costs by more than $20 \%$; consequently, early confirmation of viral reduction after initiating antiviral therapy for CHC is highly desirable [24].

To be able to predict SVR with PEG-IFN/RBV treatment, reduction of the HCV RNA viral load by week 4 is considered essential. A 2 log reduction in the HCV RNA viral load by week 4 is a prerequisite to achieving SVR with PEG-IFN/RBV treatment [25]. In our study of DFPP plus consecutive intravenous IFN- $\beta$ treatment for 4 weeks, a reduction in the viral load of $\geq 2 \log$ was achieved in $50 \%$ ( 3 of 6 patients) at 4 weeks after the start of treatment.

From the above considerations, DFPP plus consecutive intravenous IFN- $\beta$ treatment for 4 weeks is a promising regimen for non-SVR patients with genotype $1 \mathrm{~b}$ and high viral loads, previously treated with PEG-IFN/RBV therapy. Further study is needed to elucidate the SVR rate in a larger number of patients given DFPP plus IFN treatment, especially with consecutive intravenous IFN- $\beta$.

\section{Acknowledgment}

We are indebted to Yoshiko Kawamura for assistance in the preparation of the manuscript.

\section{Disclosure Statement}

No conflict of interest exists.

\section{References}

$\checkmark 1$ Hoofnagle JH, Seeff LB: Peginterferon and ribavirin for chronic hepatitis C. N Engl J Med 2006;355:2444-2451.

2 Pawlotsky JM: Therapy of hepatitis C: from empiricism to eradication. Hepatology 2006; 43:S207-S220.

-3 Manns MP, McHutchison JG, Gordon SC, Rustgi VK, Shiffman M, Reindollar R, et al: Peginterferon alfa-2b plus ribavirin compared with interferon alfa-2b plus ribavirin for initial treatment of chronic hepatitis C: a randomised trial. Lancet 2001;358:958-965.

-4 Fried MW, Shiffman ML, Reddy KR, Smith C, Marinos G, Goncales FL Jr, et al: Peginterferon alfa-2a plus ribavirin for chronic hepatitis C virus infection. N Engl J Med 2002; 347:975-982.
5 Jensen DM, Freilich B, Andreone P, et al: Pegylated interferon alfa-2A (40KD) plus ribavirin (RBV) in prior non-responders to pegylated interferon alfa-2B (12KD)/RBV: final efficacy and safety outcomes of the repeat study. Hepatology 2007;46(suppl 1):291292.

-6 Fujiwara K, Kaneko S, Kakumu S, et al: Double filtration plasmapheresis and interferon therapy for chronic hepatitis $\mathrm{C}$ patients with genotype 1 and high viral load. Hepatol Res 2007;37:701-710.

7 Fabrizi F, Martin P, Dixit V, et al: Biological dynamics of viral load in hemodialysis patients with hepatitis $C$ virus. Am J Kidney Dis 2000;35:122-129.
8 Manzin A, Candela M, Solforosi L, Gabrielli A, Clementi M: Dynamics of hepatitis C viremia after plasma exhange. J Hepatol 1999; 31:389-393.

-9 Ramratnam B, Bonhoeffer S, Binley J, et al: Rapid production and clearance of HIV-1 and hepatitis $\mathrm{C}$ virus assessed by large volume plasma apheresis. Lancet 1999;354: 1782-1785.

10 Schettler V, Monazahian M, Wieland E, Thomssen R, Muller GA: Effect of heparininduced extracorporeal low-density lipoprotein precipitation (HELP) apheresis on hepatitis C plasma virus load. Ther Apher 2001;5: 384-386. 
-11 Schettler V, Monazahian M, Wieland E, et al: Reduction of hepatitis C virus load by H.E.L.P.-LDL apheresis. Eur J Clin Invest 2001;31:154-155.

-12 Sakai A, Kaneko S, Matsushita E, Kobayashi $\mathrm{K}$ : Floating density of hepatitis $\mathrm{C}$ virus particles and response to interferon treatment. J Med Virol 1998;55:12-17.

13 Sakai A, Kaneko S, Kobayashi K: Immunoadsorption therapy for HCV infected chimpanzee. Nippon Rinsho 2001;59:1374-1378.

- 14 Yamashita T, Arai K, Sakai A, et al: Virological effects and safety of combined double filtration plasmapheresis (DFPP) and interferon therapy in patients with chronic hepatitis C: a preliminary study. Hepatol Res 2006;36: 167-175.

-15 Marson P, Boschetto R, De Silvestro G, et al: Changes in $\mathrm{HCV}$ viremia following LDL apheresis in a HCV positive patient with familial hypercholesterolemia. Int J Artif Organs 1999;22:640-644.
16 Ishida H, Tanabe K, Tokumoto T, et al: Hepatitis $\mathrm{C}$ virus decrease in patients with maintenance hemofiltration therapy. Artif Organs 2004;28:316-318.

17 Diepolder HM, Kashiwagi N, Teuber G, et al: Leucocytapheresis with Adacolumn enhances HCV-specific proliferative responses in patients infected with hepatitis $C$ virus genotype 1. J Med Virol 2005;77:209-215.

18 Sawada K, Masaki N, Hayashi S, et al: Immunomodulatory effects of selective leucocytapheresis as a new adjunct to interferon$\alpha 2 b$ plus ribavirin combination therapy: a prospective study in patients with high plasma HCV viraemia. J Viral Hepat 2005;12: 274-282.

-19 Moriyama M, Kaneko M, Matsumura H, et al: Removal of hepatitis C virus by G-1 beads in sera from patients with chronic hepatitis C. Intervirology 2005;48:84-88.

20 Hayashi N, Takehara T: Antiviral therapy for chronic hepatitis C: past, present, and future. J Gastroenterol 2006;41:17-27.

-21 Ballesteros AL, Fuster D, Planas R, Clotet B, Tural C: Role of viral kinetics under HCV therapy in $\mathrm{HIV} / \mathrm{HCV}$-coinfected patients. J Antimicrob Chemother 2005;55:824-827.
22 Asahina Y, Izumi N, Uchihara M, et al: A potent antiviral effect on hepatitis $\mathrm{C}$ viral dynamics in serum and peripheral blood mononuclear cells during combination therapy with high-dose daily interferon alfa plus ribavirin and intravenous twice-daily treatment with interferon beta. Hepatology 2001; 34:377-384.

23 Kim KI, Sasase N, Taniguchi M, et al: Interferon- $\beta$ induction/interferon- $\alpha 2$ b plus ribavirin therapy in patients with chronic hepatitis C. Int J Clin Pharm Res 2005;25:71-76.

24 Davis GL: Monitoring of viral levels during therapy of hepatitis C. Hepatology 2002;36: S145-S151.

25 Nomura H, Miyagi Y, Tanimoto H, Higashi $\mathrm{M}$, Ishibashi $\mathrm{H}$ : Effective prediction of outcome of combination therapy with pegylated interferon alpha 2 b plus ribavirin in Japanese patients with genotype-1 chronic hepatitis $\mathrm{C}$ using early viral kinetics and new indices. J Gastroenterol 2009;44:338-345. 